\title{
ГИБРИДНЫЕ ВОЙНЫ И ЦВЕТНЫЕ РЕВОЛЮЦИИ В МИРОВОЙ ПОЛИТИКЕ
}

\begin{abstract}
Аннотация: Настоящая статья посвящена определению роли гибридных войн и иветных революций в современной политике. Гибридные войны рассматриваются как новая форма вооруженного противостояния, в котором применение собственно вооруженной силь уже не является обязательным условием достижения победы над противником: «жесткая сила» в гибридной войне применяется в сочетании с невоенными методами воздействия на противника - операциями информационно-психологической войны, технологиями мягкой и умной силь, методами экономического давления, изолящии и блокады, инструментами традиционной дипломатии. Методологической основой исследования является системный, структурно-функииональный, сравнительно-политический подходы, методы анализа, синтеза, индукции, дедукции, наблюдения. Цветные революиии рассматриваются в статье как технологии организации государственных переворотов с помощью акиий массового гражданского неповиновения, перерастающих в управляемый народный бунт. Установлено, что иветные революиии не могут быть элементами гибридных войн, это разные, несочетаемые между собой форматы воздействия на противника. Однако именно иветные революиии, демонтируя политические режимы, создают условия для инициации внешней агрессии, которая затем принимает формугибридной войны. В статье также уделяется внимание современным технологиям «управляемого хаоса», которые выполняют в иветных революииях сервисные функции.
\end{abstract}

Ключевые слова: Интересы, демократия, иветные революичи, гибридные войны, государство, США, общество, политика, иенности, безопасность.

Abstract: This article is dedicated to determination of the role of hybrid wars and color revolutions in modern politics. The hybrid wars are being viewed as a new form of armed conflict, in which the use of domestic armed forces is no longer a necessary condition in order to achieve victory over the adversary: "brute force" in a hybrid war is implemented along with non-military methods of affecting the enemy - information-psychological warfare, technologies of soft and smart force, methods of economic pressure, isolation or blockade, and instruments of traditional diplomacy. The color revolutions are examined in the article as technologies of organizing government overthrows using acts of mass civil disobedience, transforming into a managed civil apprising. The author determines that color revolutions cannot be elements of hybrid wars, as they are different and incompatible with each other forms of pressure upon the opponent. But it is in namely the color revolution that by dismantling political regimes, create the environment for initiation of external aggression, which then takes on a shape of a hybrid war.

Keywords: Politics, society, USA, state, hybrid wars, color revolutions, democracy, interests, values, security.

\section{1. Гибридная война и цветная революция: к вопросу о соотношении понятий}

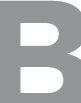

современном мире тематика гибридных войн и цветных революций продолжает набирать все большую популярность. Это не случайно: мировая цивилизация на современном этапе своего развития столкнулась с принципиально новыми инструментами формирования новой политической реальности, чрезвычайно эффективными в условиях кризиса однополярного мира, но, вместе с тем, представляю- щими исключительную опасность для современных наций-государств. Эта опасность исходит из понимания того, что гибридные войны и цветные революции - явления сравнительно новые, с них только недавно сняли «кавычки», и для этих явлений, способных потрясать и разрушить сами основы современного общества, еще не выработано сбалансированных противовесов, противоядий, сдерживающих механизмов, ограничительных норм международного права. В военно-политическом плане «понятие «гибридная война» может объединять широкий диапазон действий, осуществляемых про- 
тивником с использованием военных и иррегулярных формирований с одновременным привлечением гражданских компонентов» [1], а понятие «цветная революция» включать в себя целый сценарий государственного переворота и демонтажа политического режима, успешно маскирующийся под народный бунт. Кроме того, сегодня технологиями гибридных войн и технологиями цветных революций практически на праве монополии владеют Соединённые Штаты, которым даже сами термины «гибридная война» и «цветная революция» обязаны своим происхождением, и любое государство, отстаивающее свое суверенное право на проведение независимой внешней политики, тем самым, рискует стать мишенью для применения этих инструментов и технологий.

Сегодня, когда говорят о гибридных войнах и цветных революциях, довольно часто смешивают и путают эти понятия. Более того, после появления в широком научном дискурсе термина «гибридная война» появилась тенденция объединить все известные формы, методы и технологии вооруженной борьбы под одним «зонтичным» брендом - понятием гибридной войны, являющейся своеобразной надстройкой над появившимися ранее в научном дискурсе и потому значительно более изученными традиционными, информационными, психологическими, сетевыми, сетецентричными, прокси-войнами и цветными революциями (войнами не являющимися). Это тоже не случайно: между гибридными войнами и цветными революциями, помимо принципиальных различий, существует много общего: оба этих явления рассматриваются как на феноменологическом (как явление), так и на технологическом уровне (как технология и инструмент политического воздействия); оба явления еще недавно встречались исключительно в кавычках, что говорит о том, что не было еще выработано специальной терминологии, точно описывающей эти явления и принадлежащей только им; наконец, оба этих понятия даются синтетическими конструкциями, базирующимися на известных понятиях «война» и «революция» с уточняющими прилагательными, меняющими их смысл.

Действительно, гибридная война по своей сути находится ближе всего к понятию «война», а цветные революции, являющиеся технологиями организации государственных переворотов, успешно маскируются под революции истинные. Вместе с тем, сам факт наличия прилагательных ставит под сомнение корректность отнесения гибридных войн к войнам и цветных революций - к революциям: понятия «война» и «революция» не нуждаются в уточнениях (также как насто- ящая демократия не может быть суверенной); строго говоря, гибридные войны - это не совсем войны, хотя и имеют с известными нам войнами много общего, а цветные революции - не совсем революции, больше того - совсем не революции. Тем не менее, также как и в случае с определением «информационная война». Мы вынуждены пользоваться этим приемом, описывая новые явления через сравнения и аналогии с теми явлениями, событиями и процессами, смысл которых для нас предельно ясен. Так новая терминология рождается на прочном фундаменте аксиоматики политической науки, которая принята всем экспертным сообществом и которую никто не ставит под сомнение. Этот подход, помимо всего прочего, имеет еще и объективный характер: современный мир меняется с такой скоростью, динамика этих изменений настолько высока, что ежегодно возникают новые явления, не имеющие прямых аналогов в мировой истории, которые требуют своего определения и описания. Мир развивается быстрее, чем понятийный аппарат, способный описать эти изменения.

Тем не менее, необходимо признать, что при всей эклектичности и публицистичности термины «гибридные войны» и «цветные революции» описывают объективные, реально существующие явления, и эти явления все больше распространяются в современном мире, оказывая заметное влияние на мировой политический процесс, политическую динамику и на трансформацию системы международных отношений. Наличие в их названии терминов «война» и «революция» указывают на их высокую социальную опасность, играя сигнальную функцию, и эта оценка их опасности правильна. При этом не могу разделить мнение тех ученых, которые при этом стремятся нивелировать значение этих новых явлений, утверждая, что гибридные войны существовали в истории человечества всегда, любая война является по своей сути гибридной: я убежден, что качественный эволюционный скачек и гибридные войны, и цветные революции совершили сравнительно недавно - в конце 20 века, или даже позже, а их схожесть с войнами и «бархатными революциями» прошлого говорит в первую очередь о том, что ни одно принципиально новой явление не возникает в вакууме, оно всегда является результатом эволюционного процесса и всегда базируется на более ранних и более примитивных формах. Эти формы передают часть своих отличительных черт и технологических решений новым явлениям, но именно появление новых явлений способно преодолеть технологический, военно-стратегический, цивилизационный барьер, которые прежние формы преодолеть не 
DOI: $10.7256 / 1811-9018.2015 .7 .15832$

При цитировании этой статьи сноска на доі обязательна

\section{Право и политика 7 (187) • 2015}

в состоянии. Так происходит фазовый переход от одной политической реальности к другой, с одного витка эволюции к другому, более высокому, от набора аминокислот в первичном «бульоне» к первым формам белковой жизни. Так и в случае с гибридными войнами: по своему содержанию гибридные войны - это качественно новое понятие, более широкое, чем просто совокупность современных форм и методов вооруженной борьбы в традиционной, информационной, экономической и других сферах. То же самое можно сказать и о цветных революциях после событий «Арабской весны», кризиса 2013-15 гг. в Украине и «зонтичной революции» в Гонконге.

\section{2. Точки сопряжения гибридных войн и цветных революций}

Для того чтобы точно определить, как именно соотносятся между собой гибридные войны и цветные революции, необходимо сопоставить их между собой, выявить сходства и различия, связи, объединяющие их в тех событиях, где они находят свое проявление. Прежде всего, необходимо определиться с тем, что же такое гибридные войны, поскольку на этот счет существует масса различных мнений, зачастую противоречащих друг другу. Точного и однозначного определения гибридным войнам нет, известно лишь, что впервые этот термин был вброшен в оборот американскими фабриками мысли, такими как RAND Corp., Стэндфордский университет и др. Гибридные войны предполагают комбинированное использование стратегий, характерных для различных видов современных войн традиционной, информационной, идеологической, экономической, для нанесения ему военного поражения, для поражения сил и средств противника, достижения над ним военно-стратегического превосходства и силового принуждения к миру на условиях победителя. При этом гибридные войны могут вестись как в традиционной форме (предполагающей наличие линии фронта, тылов различной глубины и действия регулярной армии), так и в сетецентрической, где линия фронта отсутствует в принципе. В гибридной войне именно информационные операции (операции информационной войны) могут иметь решающее значение для принуждения противника к капитуляции, а боевые операции вооруженных сил могут играть сервисную роль, обеспечивая организаторов информационных войн пиарматериалом, необходимым для информационных атака на сознание и подсознание противника в целях как нанесения ему прямого урона (информационным оружи- ем), так и с целью скрытого управления его сознанием и поведением. Именно такую картину мы наблюдали во время второй войны в Ираке, где боевые действия американских войск являлись конвейером для производства пиар-новостей и «мыльных опер» про войну, в операциях в Афганистане, Ливии, Сирии и теперь - в определенной мере - в гражданской войне в Украине. В гибридных войнах достигается не просто эффект сочетания различных видов и форм противоборства, напротив, различные формы и методы ведения войны гибридизируют традиционные концепции вооруженной борьбы, прививают их от новых вызовов и угроз, обеспечивают эффект глубокой взаимной интеграции и симбиоза различных поражающих факторов и технологий. При этом целью гибридной войны по-прежнему остается классическая цель войны традиционной - военное поражение, уничтожение и капитуляция противника. Это важно понимать, потому что в противном случае понятие гибридных войн быстро размывается и приобретает спекулятивную окраску.

В этом и заключается основное отличие гибридной войны от цветной революции: в отличие от гибридной войны, главной и единственной целью цветной революции является организация государственного переворота, и ничто иное. Цветные революции - это технологии государственных переворотов в условиях искусственно созданной нестабильности, в которых давление на власть осуществляется в форме политического шантажа, а инструментом шантажа выступает молодежное протестное движение, организованное по специальной сетевой схеме. Цель цветных революций - государственный переворот, после его успешного осуществления цветная революция заканчивается. На практике цветные революции довольно часто перерастают в вооруженные мятежи или сочетаются с военной интервенцией, но применение военной силы в цветных революциях - скорее исключение, чем правило, для технологов «цветников» это мера вынужденная. Но цветные революции, являясь технологиями демонтажа политических режимов, создают условия для вмешательства других государств во внутренние дела страны, ставшей жертвой цветной революции, для военной интервенции, военных мятежей, гражданских войн. В этом плане последствия цветных революций могут быть не менее катастрофичными, чем сама цветная революция. Это мы хорошо видим на примере гражданской войны в Украине.

Таким образом, все же наличие существенных отличий не позволяет полностью объединять современные гибридные войны, ставшие новой формой и со- 
держанием современных вооруженных конфликтов, и цветные революции, ставшие инструментами организации государственных переворотов и принудительного демонтажа политических режимов. Гибридная война - это последовательность боевых операций, цветная революция - это технология. Это не позволяет рассматривать цветную революцию в качестве одной из фаз гибридной войны, хотя технологии цветных революций могут использоваться в гибридных войнах, в строгом соответствии с их собственными целями и задачами (целями и задачами гибридных войн). Вместе с тем, все же есть кое-что, что их объединяет: цветные революции довольно часто становятся прелюдией для гибридной войны, формируя условия, необходимые для перевода конфликта в военную фазу; примером этого может служить нынешняя Украина. При этом часто реализовывается следующая цепочка: цветная революция (инцидент-протест-майдан) - вооруженный мятеж - гражданская война - гибридная война. Цветная революция при этом играет роль спускового механизма гибридной войны, а ее технологии могут использоваться организаторами гибридных войн в целях провоцирования вооруженного конфликта, дальнейшее течение которого будет проходить в гибридной форме.

\section{3. Цветные революции как инструменты демонтажа политических режимов}

Проблемы демонтажа современных политических режимов и связанная с ними проблематика цветных революций в современных условиях приобретают чрезвычайную остроту и актуальность. Связано это не только с тем, что события в Украине при детальном рассмотрении в точности повторяют сценарий цветных революций в Северной Африке и на Ближнем Востоке, получивших название «Арабской Весны», в частности - революции в Египте, что указывает на неслучайность данных событий. Причина в том, что на смену традиционным, привычным для мирового сообщества инструментам демонтажа приходит новое поколение более тонких инструментов, сочетающих силовые методы воздействия с технологиями манипулятивного управления массовым сознанием и массовым поведением широких масс гражданского населения.

В мировой истории проблемы, связанные с демонтажем политических режимов, возникали всегда. Но прежде инструментами этого демонтажа выступали в основном силовые методы в их классическом понимании, применявшиеся в ходе вооруженных переворотов, локальных вооруженных конфликтов, гражданских войн и военных интервенций. И мировое сообщество сумело выработать действенные методы противодействия этой угрозе и создать эффективные механизмы политического регулирования этих процессов, в том числе на международном уровне: кто бы и как бы ни критиковал ООН, эта организация действует, и ее потенциал и возможности по управлению политической стабильностью и урегулированию международных конфликтов даже в условиях распада Вестфальской системы далеко не исчерпаны. Острота проблемы, связанная с угрозой вооруженных переворотов в различных странах мира, не перестает быть актуальной и не снимается с повестки дня, но в целом для мирового сообщества эта категория угроз является знакомой, и мировое сообщество знает, как на нее реагировать.

Вместе с тем, мир меняется, и на смену технологиям вооруженных переворотов приходят более тонкие технологии цветных революций, которые умело маскируются под истинные революционные движения и практически не встречают сопротивления со стороны как стран с вполне уже сложившейся демократией, так и государств восточного типа, сохранивших традиционный жизненный уклад. Повторение сценария цветных революций в Украине вызывает обоснованную тревогу, поскольку возникает и крепнет уверенность в том, что Украина - далеко не конечный пункт этого сценария, а разменная карта в той геополитической игре, в которой главный удар американских режиссеров цветных революций может быть направлен на Россию, Китай и Казахстан.

Причины возросшего внимания к цветным революциям кроются в том, что в течение последних трех лет в целом ряде государств, с вполне устойчивыми политическими режимами, произошли государственные перевороты, приведшие к полному или частичному демонтажу политических режимов, долгие годы успешно сопротивлявшихся с внешними и внутренними врагами: так, египетский, тунисский, сирийский и ливийский режимы успешно противостояли исламизму. При этом в сценариях смены политических режимов в этих странах наблюдается поразительное сходство, в котором можно усмотреть многократное повторение одного и того же шаблона или организационной схемы, в которой угадываются общие черты так называемых бархатных революций, уничтоживших коммунистические режимы в странах восточной Европы после распада СССР.

Такое совпадение вряд ли можно назвать случайным, поскольку вероятность точного совпадения сце- 
DOI: $10.7256 / 1811-9018.2015 .7 .15832$

При цитировании этой статьи сноска на доі обязательна

\section{Право и политика 7 (187) 2015}

нариев смены политических режимов в странах, заметно различающихся и по уровню политической организации власти, и по уровню социально-экономического развития, и по спектру нерешенных проблем, сравнительно (если не сказать ничтожно) мала. В этом плане Сирия и Ливия кардинально отличаются от Украины и Грузии, однако, несложно отметить, что революция 2014 года в Украине (получившая название евромайдана) в точности совпадает со сценарием революции Арабской Весны в Египте, вплоть до стиля поведения противоборствующих сторон.

Bсе это может свидетельствовать о том, что на примере различных стран и регионов мы имеем дело с одним и тем же явлением - результатом применения технологий цветных революций. Однако, несмотря на яркое брендовое название, ничего революционного в них нет. Даже западные СМИ сегодня отмечают, что цветные революции, которые они называют технологиями проведения операций по экспорту демократии через акции гражданского неповиновения, настолько отточены, что их методы превратились в руководство по смене политических режимов.

Цветные революции - это технологии осуществления государственных переворотов и внешнего управления политической ситуацией в стране в условиях искусственно созданной политической нестабильности, в которых давление на власть осуществляется в форме политического шантажа с использованием в качестве инструмента шантажа молодежного протестного движения.

Несмотря на существенные различия государств, в которых они вспыхивают, между собой (в геополитическом, социальном, экономическом плане и международном положении), все они укладываются в одну и ту же организационную схему, предполагающую организацию по шаблону молодежного протестного движения, преобразования его в политическую толпу и использование этой силы против действующей власти в качестве инструмента политического шантажа. Это прямо указывает на то, что цветные революции в принципе не могут быть реализацией объективных надежд и стремлений большинства населения.

Цель любой цветной революции - осуществление государственного переворота, то есть захват и удержание власти насильственным путем.

Объектом цветной революции выступают власть и властные отношения, предметом - политический режим.

У цветных революций есть необходимое и достаточное условия их успешной реализации.
Необходимое условие осуществления цветной революции - наличие политической нестабильности в стране, сопровождающейся кризисом действующей власти. Если политическая ситуация в стране стабильна, ее нужно искусственно дестабилизировать.

Достаточное условие - наличие специально организованного (по особой сетевой форме) молодежного протестного движения.

Отличительные черты цветных революций:

- в цветных революциях воздействие на власть осуществляется в особой форме - форме политического шантажа.

- основным инструментом воздействия на власть выступает молодежное протестное движение.

Цветные революции только внешне напоминают настоящие революционные движения - в отличие от революций настоящих, вызванных объективным развитием исторического процесса, цветные революции - это технологии, успешно маскирующиеся под стихийные процессы. Они отличаются почти театральным уровнем драматургии, который западные политологи старательно пытаются выдать за самопроизвольное и стихийное проявление воли народа, внезапно решившего вернуть себе право управлять собственной страной.

В основе технологического сценария цветной революции лежит англосаксонская (североамериканская) идеология демократизации, предполагающая экспорт демократии, демократических институтов и ценностей в сопредельные страны. Технологии цветных революций на практике умеют применять только их авторы и разработчики - англосаксы. В любой стране, где начала разворачиваться цветная революция, следует искать северомериканский след.

В основе объяснения причин цветных революций лежат две версии: версия о стихийности и версия об инсценированности цветных революций (о случайности и неслучайности). Обе версии имеют право на существование и не являются бесспорными. Вместе с тем, у каждой цветной революции есть свои признаки, которые выдают в ней технологию.

Во-первых, это особый внешнеполитический почерк англосаксов, их отличительный стиль работы.

Во-вторых, это строгое соответствие плана любой революции базовому шаблону - все цветные революции развиваются по одному и тому же сценарию, использующего одну шаблонную схему.

В-третьих, это то, каким образом организуется и как используется молодежное протестное движение, которым управляют с помощью технологий рефлексив- 
ного управления (которые также являются американским изобретением).

В-четвертых, есть определенные повторяющиеся особенности в подборе и выдвижении революционных лидеров.

В-пятых, в некоторых цветных революциях начисто отсутствует революционная идеология, что позволяет распознать в них подделку. Связано это с тем, что американцы - авторы цветных революций - не всегда понимают менталитет и психологию народа, которым они хотят принести «ценности истинной демократии», и не могут предложить им идеологию, которая будет органично принята всеми слоями общества.

Цветные революции используют фактор военной силы как сервисную функцию, к которой их сценаристы и технологи прибегают в случае крайней необходимости, ее использование носит скорее вынужденный и побочный характер. Вместе с тем, современные цветные революции действительно создают условия и поводы для последующей военной интервенции.

Модель цветной революции состоит из пяти основных этапов:

1. Любая цветная революция начинается с формирования в стране организованного протестного движения - основной движущей силы будущей цветной революции.

На первоначальном этапе, до открытого выступления, протестное движение формируется в виде сети, состоящей из конспиративных ячеек, каждая из которых состоит из лидера и трех-четырех состоящих у него на связи активистов. Такие сети объединяют тысячи активистов, составляющих ядро будущего протестного движения. Многие из них перед тем, как стать лидерами ячеек, проходят обучение в специальных центрах, специализирующихся на вопросах содействия демократизации.

Рекрутируют активистов из молодежной среды, чрезвычайно подвижной и легко увлекаемой различными яркими призывами и лозунгами. Сетевой принцип организации протестного движения напоминает принцип организации глобальных террористических сетей - по сути, это одна организационная технология.

2. Из подполья эта сеть выходит на улицы крупных городов одновременно и по условному сигналу, который носит название инцидента. Таким инцидентом может стать любое событие, шокирующее общество и получившее мощный общественный резонанс. Как правило, его инициируют специально. Очень важно, чтобы инцидент привлек внимание всего общества и стал предметом широкого обсуждения, интерпретации, нарастания всеобщего возбуждения и инициирования стихийных форм массового поведения.

3. После того, как инцидент произошел, протестная сеть выходит из подполья на улицы, где группы активистов из ячеек становятся катализатором стихийных массовых процессов, вовлекающих в этот процесс все большие слои населения. Включаются механизмы конфликтной мобилизации, одним из которых являются «твиттерные революции».

Ячейки начинают быстро обрастать гражданами, вовлекаемыми в стихийное протестное движение, принять участие в котором их толкает в основном страх за свое будущее. Общая тревожность настроений ведет к тому, что сознание людей переходит в так называемое пограничное состояние и становится подверженным массовым паническим реакциям, всеобей истерии, часто проявляющихся на уровне рефлексов и инстинктов. С этого момента остается только один шаг от превращения протестных масс из сообщества протестующих в толпу.

4. Следующий шаг в схеме цветной революции формирование политической толпы. Для этого выбирается достаточно большая площадь (майдан), где могли бы разместиться значительные массы народа.

Активисты ведут свой протестный электорат на такой майдан, где в ходе многочасового митинга происходит полное слияние участников в единую массу - толпу. Происходит эмоциональное слияние отдельных личностей с толпой, в которой для идентификации свой-чужой начинает использоваться яркая «революционная» опознавательная символика.

В этих условиях на толпу воздействуют с помощью технологий воздействия на подсознание, внедряя новые ценности и императивы, перепрограммируя человека. Именно такие технологии применяются в протестантских тоталитарных сектах.

Создаются условия для поддержания устойчивого существования и функционирования толпы - материальное обеспечение, палатки, горячее питание, одежда, деньги активистам, средства нападения (арматура, ...) и т.д. Действует хорошо организованная «служба тыла».

5. От имени толпы к власти выдвигаются ультимативные требования, под угрозой массовых беспорядков и - реже - физического уничтожения. В том случае, если власть не выдерживает этого напора, стихия ее сметает. Если власть принимает вызов и выражает готовность сопротивляться, толпа становится основным таранным фактором удара, который на- 
DOI: $10.7256 / 1811-9018.2015 .7 .15832$

При цитировании этой статьи сноска на dоі обязательна

\section{Право и политика 7 (187) • 2015}

носят по власти авторы цветной революции. В дальнейшем такая революция неизбежно перерастает в мятеж, а в некоторых случаях - в гражданскую войну, сопровождающуюся военной интервенцией.

Современные события в Украине (2013-14 гг.) также имеют отношение к цветным революциям - они в точности повторяют Египетский сценарий. России, опираясь на украинский опыт, необходимо готовиться к тому, что она станет следующей в перечне мишеней англосаксонских цветных революций. Стране необходима государственная концепция по противодействию цветным революциям, как в России, так и в целом на пространстве СНГ, подкрепленная дорожной картой ее реализации. Украина - это последняя генеральная репетиция такой революции, обкатка ее на стране со сходным менталитетом, культурой и цивилизационной идентичностью.

Интересно, что в последних работах западных авторов (в том числе британских и французских) появляются оценки цветных революций, идущие в разрез с навязываемыми США представлениями о цветных революциях как инструментах демократизации и формирования демократического мира. Так, некоторые ученые начинают - пока еще довольно осторожно утверждать, что ни одна из цветных революций на Ближнем Востоке и в Северной Африке не принесла процветание христианскому миру: напротив, Арабская весна всколыхнула и заставила выйти из глубокого подполья наиболее опасные, экстремистски настроенные силы, представляющие исламизм, с которыми теперь западным странам приходится иметь дело уже на официальном уровне. Арабская весна, начавшаяся под лозунгами демократизации арабского Востока, ускорила процесс отступления христианства под натиском радикального ислама, которое с началом цветных революций Арабской весны многократно усилилось. Арабская весна, сделанная на деньги и с помощью американских и западноевропейских союзников, стала для Западной христианской цивилизации, и без того уже переживающей острый кризис, началом «Христианской зимы». Это заставляет серьезно задуматься о том, какую роль сегодня на самом деле играют цветные революции в мировой политике и в формировании нового миропорядка, и каким он будет, этот новый миропорядок, если волну цветных революций вовремя не остановить.

\section{4. Цветные революции и мягкая сила}

Цветные революции часто называют технологиями или инструментами «мягкой силы», понимаемой в том ракурсе, который дал для этого термина Дж. Най. Этот подход, основанный на принципе аналогии (внешне цветные революции - это несиловые технологии смены политических режимов), не совсем точен и часто вводит в заблуждение, заставляя считать цветные революции более мягкой и поэтому более прогрессивной и менее социально опасной формой воздействия на авторитарные режимы. Тем самым разворачивается кампания по пропаганде цветных революций в пику любым формам собственно вооруженных переворотов. На наш взгляд, трудно определить, что на самом деле является более опасным явлением для международной безопасности в целом: цветные революции или локальные вооруженные конфликты, и современный Ближний Восток, погруженный цветными революциями в «управляемый» хаос, является полным тому подтверждением. Все же, представляется довольно очевидным, что современные цветные революции по своей природе - это не форма проявления «мягкой силы». Цветные революции - не мягкая сила; это инструменты взлома демократических режимов переходного типа, скопированных с англосаксонских образцов незападными странами, которые имеют признаки имитационности. Можно утверждать, что американцы не только создали модель демократического устройства государства, ориентированную «на экспорт», но и позаботились о создании специальных инструментов, предназначенных для ее слома и демонтажа, если в этом вдруг возникнет необходимость. В современном мире такими инструментами, играющими роль своеобразных отмычек для взлома политических режимов западного либерального типа, являются технологии цветных революций.

\section{5. Цветные революции сквозь призму гибридных войн}

При всей неоднозначности отношения современного общества к цветным революциям все же следует признать, что большинство из них - чрезвычайно эффективный инструмент преобразования политической картины мира.

В современной политической реальности цветные революции - одно из наиболее разрушительных и наименее изученных явлений мировой политики. Именно с цветными революциями сегодня связывают технологические схемы и приемы осуществления принудительного демонтажа политических режимов в государствах с неустойчивыми формами демократии, построенной по западным лекалам, или в государствах традиционного восточного типа, в которых демократическая форма правления довольно часто в принципе отсутствует. 
При этом сопровождающее госперевороты разрушение (или, точнее, демонтаж) государственности и утрата суверенитета выдается за процесс демократизации, модернизации, либерализации или «приобщения к европейской культуре», и несколько реже - за действие «мягкой силы».

Практически всегда прямым следствием цветных революций, помимо осуществления их главной (и единственной) задачи - совершения государственного переворота, становится погружение страны в политический хаос, который американцы любят называть «управляемым», переход страны под внешнее управление (вспомните назначение иностранцев-«легионеров» на ключевые посты в Кабинете министров современной Украины), а также гражданская война, геноцид мирного населения и военная интервенция.

Страна, пережившая переворот, не становится от этого более свободной; напротив, в подавляющем большинстве случаев она попадает в тяжелую кабальную зависимость от США и их военно-политических союзников, превращаясь в их колонию.

Дальнейшая судьба этих государств печальна: люди, экономика, природные ресурсы становятся расходным материалом для инициирования цветных революций в других странах, для провоцирования новых международных конфликтов, в которых особая роль отводится новым акторам - государствам-провокаторам, ведомым марионетками, поставленными Вашингтоном, готовыми на все ради расположения и благосклонности своих настоящих американских «хозяев».

Довольно часто страны-провокаторы (такие как Грузия в российско-грузино-югоосетинском конфликте 2008 года, Украина в гражданской войне в Донбассе или некоторые страны Балтии, предоставляющие свою территорию для ударных группировок НАТО, сосредотачивающихся у западных границ России) получают от США статус основного союзника вне блока НАТО и миллиардные кредиты на закупку новейших вооружений и военной техники.

При всей неоднозначности отношения современного общества к такого рода мятежам все же следует признать, что большинство из них - чрезвычайно эффективный инструмент преобразования политической картины мира, который сегодня находится в неустойчивом и несбалансированном состоянии, называемом «кризисом однополярного мира».

При этом довольно часто свет истинной - «незамутненной» - демократии народам мира несут те самые силы, с которыми США - источник и главный организатор всех бунтов - борются всеми возможными (в том числе военными) способами: в цветных революциях «арабской весны» носителями демократических ценностей выступили монархии Персидского залива Саудовская Аравия и Катар, жесткие авторитарные государства, в которых демократией даже не пахнет.

В Египте главной движущей силой «демократизации» общества стали «Братья-мусульмане», в Ливии исламисты, в Сирии - все те же исламисты, представленные широким спектром террористических организаций - от сирийских ячеек «Аль-Каиды», выставившей свои отряды для борьбы с Б. Асадом, от «Талибана» до «Исламского государства Ирака и Леванта» (ИГИЛ).

На Украине для Соединенных Штатов Америки передовым отрядом «демократизации» общества и его «приобщения к европейским ценностям» стали неонацисты, целое поколение которых США вырастили за 20 лет «независимости» страны, прошедших с момента распада Советского Союза.

Несмотря на то, что даже при поверхностном рассмотрении несложно увидеть технологию, причем одну-единственную, применяющуюся последовательно (с незначительными доработками) к различным странам как либерально-демократического, так и авторитарного типа, довольно большое количество политиков и ученых продолжают рассматривать перевороты на феноменологическом уровне, как социальное явление, природа которого связана с процессами модернизации традиционных обществ, обеспечивающих им скачкообразный переход в новый, более современный уклад.

Основными мотивами такого подхода, помимо принципа взвешенности, непредвзятости, историзма и следующей из него позиции принципиального отрицания любых «конспирологических» инсинуаций, нередко выступает стремление упростить себе жизнь.

Если цветные революции - явление объективное, связанное с особенностями протекания исторического процесса на современном этапе развития общечеловеческой цивилизации, то противодействовать им - дело заведомо бесполезное, так как социальное явление устранить из жизни общества нельзя, но можно пытаться регулировать его уровень социальной опасности, минимизируя издержки и максимизируя конструктивные качества.

Но при этом не очень понятно, почему именно в последние десятилетия, в эпоху просвещенной демократии и глобального демократического общества, наиболее эффективным инструментом разрешения этих самых объективных противоречий стали сценарии и схемы государственных переворотов, единственная цель которых - насильственный захват и удержание власти, 
DOI: $10.7256 / 1811-9018.2015 .7 .15832$

При цитировании этой статьи сноска на доі обязательна

\section{Право и политика 7 (187) 2015}

причем любыми способами, в том числе насильственными, в форме вооруженного мятежа и развязывания террора против собственного мирного населения (пример - Украина 2014-2015 гг.).

В целом же феноменологический подход к цветным революциям ведет к фактическому оправданию их организаторов и исполнителей, снятию с них клейма уголовных преступников, ответственных за разрушение государства, утрату им (полностью или частично) суверенитета, за жертвы среди мирного населения, за геноцид, этнические чистки и военные преступления (такие, которые сейчас совершают ВСУ и многочисленные «добровольческие» карательные батальоны в Донбассе).

В том, что цветные революции являются современной формой истинных революций, таких как кубинская или никарагуанская, есть все основания сомневаться: практически все из них, начиная от бархатных в Восточной Европе и заканчивая украинским евромайданом и «зонтичной» в Гонконге, сделаны как под копирку по одной и той же схеме, сценарию, или, как его называют в Великобритании, «демократическому шаблону».

Все разговоры о демократизации и мягкой силе, транзите демократических ценностей (или дрейфе их же) выглядят при этом как легенда прикрытия (выражаясь языком разведчиков и шпионов), так как именно этим они и являются.

Их сила в другом: перевороты дают гарантированный результат при строгом соблюдении технологического цикла.

Эти технологии действуют как часы и дают сбои только в редчайших случаях, что делает их высокоэффективным и потому опаснейшим инструментом демонтажа современных политических режимов. И сегодня он находится в руках (в эксклюзивном владении) североамериканских англосаксов - прямых авторов и разработчиков этих технологий: только они умеют этот инструмент применять таким образом, чтобы не нарушить технологический цикл. И делают это весьма успешно.

Вместе с тем любая технология предполагает повторение одной и той же последовательности элементарных операций; организационная технология предполагает многократное чередование одной и той же последовательности этапов или фаз. Цветные революции не являются исключением: развитие событий в них всегда проходит через шесть ключевых этапов, выстраивающихся в единую технологическую цепочку.

В этой особенности кроется главная возможность организации системного противодействия им: если речь идет о применении одной и той же технологии, то действия и тактику поведения ее организаторов, исполнителей и сценаристов всегда можно просчитать на много ходов вперед.

Успешность операции целиком зависит от строгости соблюдения технологического цикла: каким бы сильным и гениально прозорливым ни был ваш противник, он будет вынужден следовать правилам и неизбежно пройдет все этапы, предусмотренные базовым сценарием цветной революции, и в той самой последовательности, которая указана в технологической «инструкции к применению».

Это, в свою очередь, означает, что, своевременно выявив признаки подготовки к мятежу и определив, на каком этапе эта операция находится, можно точно вычислить контрольную точку процесса, в которую противник обязательно придет, следуя требованиям и логике технологического процесса, и в которой он окажется уязвим для заранее спланированной и подготовленной контратаки.

С точки зрения эволюции цветные революции и гибридные войны развиваются по разным траекториям, что также подчеркивает тот факт, что это явления, имеющие различную природу: цветные революции стремятся выработать такую технологическую схему воздействия на политические процессы, при которой применение прямой вооруженной силы станет излишним и просто вредным для достижения конечной цели - организации государственного переворота под прикрытием массовых протестов; гибридные войны, напротив, ищут для прямой вооруженной силы новых форматов, моделей и ниш применения. Возможно, это прямой пример того, как именно классические инструменты политического воздействия - жесткая и мягкая силы - пытаются приспособиться к новой политической реальности, к новой среде, которая не является дружественной и податливой ни для чисто «мягких», ни для чисто «жестких» технологий. При этом эволюция жестких методов воздействия идет по пути гибридизации, «прививки» им «мягких» вакцин, часть из которых гибридные войны имплементируют в свой набор инструментов политического воздействия, комбинируя их и сочетая с «жесткими» инструментами (так появляется «умная сила»), а часть - отторгают, вырабатывая на них «антидот»; эволюция же «мягких» методов, к которым относятся классические схемы и технологии цветных революций, идет по пути «навешивания» на классическую схему, применявшейся в «бархатных революциях» в Восточной Европе, новых «гаджетов» - сервисных функций, предполагающих более широ- 
кое использование жесткой силы, таких как технологии «управляемого хаоса». Так, в последних версиях цветных революций - например, в Украине 2013-14 гг. - обязательным элементом сценария цветной революции стала работа снайперов по активистам майдана и просто мирным гражданам с целью повышения уровня агрессивности толпы, собравшейся на этом самом майдане. Это - типичный пример применения инструментов жесткой силы, имплементированных в более «мягкую» структуру сценариев цветных революций.

Именно на поле этих гаджетов технологии гибридных войн и цветных революций взаимно пересекаются: это информационные войны (операции и инструменты информационно-психологической войны) и технологии управляемого хаоса. И то, и другое успешно и эффективно используется и в гибридных войнах, и в цветных революциях, но - для достижения разных целей. В последнее время появилась мода на дальнейшее усложнение терминов: многие эксперты стали говорить о гибридной «хаос-войне», продолжая конструировать сущности и смешивая различные понятия. Во многом это размножение терминов не является оправданным: их содержательная часть требует тщательного уточнения и конкретизации, с опорой на методологический аппарат политической, военной и иных смежных наук.

\section{6. Противодействие цветным революциям}

Следует отметить, что операция США по переформатированию постсоветского пространства в определенной мере сегодня касается и России. Не секрет, что в организации протестного движения «За честные выборы» виден почерк режиссеров цветных революций, в котором наблюдаются все ее атрибуты - начиная от символики («белых ленточек») и заканчивая уровнем организации митингов и манифестаций, требующих вложения огромных финансовых средств. И совсем не случайно в Москву новым послом США именно в тот период был назначен Майкл Энтони Макфол, талантливый автор и режиссер «оранжевой революции» на Украине и «революции роз» в Грузии.

В целом, сценарий «революции белых ленточек» полностью соответствует классическим сценариям цветных революций в Восточной Европе и на постсоветском пространстве, за исключением одной детали: этот сценарий - усеченный, рассчитанный скорее ан демонстрацию мощи, чем на реальный результат (смену режима). На это указывают прежде всего объемы финансирования, которые были выделены Госдепом США на организацию цветной революции в Рос- сии: один из лидеров оппозиционеров, приехавший в 2012 оду на Селигер и отрицавший какое-либо участие США в событиях на Болотной площади, проговорился, что сумма, выделенная США на организацию «белых ленточек», была чуть больше чем сумма, потраченная на «революцию роз» в Грузии. Эта сумма, конечно, достаточна для Грузии или Украины, но ничтожно мала для России, в которой цветная революция только тогда будет иметь успех, если мятеж одновременно вспыхнет в двух десятках крупнейших городов и региональных центров. Все это указывает на то, что основная задача была - попугать российскую власть и заставить ее полностью погрузиться во внутренние проблемы, на время перестав следить за международной обстановкой.

Надобность в революции белых ленточек у США пропала после того, как стало ясно, что наземная операция против Ирана откладывается на неопределенный срок - виной тому оказалась Сирия, с которой не удалось разобраться также быстро как с Ливией. После этого «революцию» в России по команде из Вашингтона свернули - американцы прагматично решили, что больше на нее тратить деньги не стоит.

В 2011 году, говоря о последствиях падения режима Каддафи, сенатор Д. Маккейн выразил мнение, что смена власти в Ливии даст сигнал и другим странам, «стремящимся к демократическим преобразованиям»: «это будет своеобразным посланием и для Башара Acaда, и для Йемена, и для других диктаторов. Эхо «арабской весны» услышат во всем мире - от России и Китая до Израиля. С тех пор как молодой человек сжег себя на улице, положив начало волнениям в Тунисе, мы видим стремительно меняющийся мир», - заявил Маккейн. Таким образом, Маккейн не исключает, что следующей целью волны «финиковых революций» будет Китай и Россия [2]. В 2014 году в Гонконге развернулась «революция зонтиков», которая также относится к цветным революциям с особой - «усеченной» - схемой, аналогичной «белым ленточкам» в России. В Украине в 2014 году в результате «цветного» переворота началась гражданская война, в которой марионеточное правительство Порошенко, развернувшее политику геноцида в отношении населения юго-восточных областей Украины, получило полную и безоговорочную поддержку Государственного департамента США.

Высказывание сенатора Маккейна, несомненно, носит характер «пробного шара»; сам же он заявляет это все вполне искренне, не замечая, что им манипулируют. «Пробный шар» всегда направлен на провоцирование общественного мнения, в том числе мнения политических и военных союзников и противников США, 
DOI: $10.7256 / 1811-9018.2015 .7 .15832$

При цитировании этой статьи сноска на dоі обязательна

\section{Право и политика 7 (187) • 2015}

на высказывание своего отношения к возможности такого вмешательства во внутренние дела перечисленных стран, а также на высказывание собственных оценок реальности такого вмешательства. И хотя реальный политический вес Маккейна ничтожен, а одиозность его фигуры известна всем, к этому его высказыванию все же следует относиться серьезно: такого рода прощупывание политической ситуации на предмет ее лояльности по отношению к новым целям и планам внешней экспансии США наводит на мысль, что эти планы уже разаботаны и ждут своего часа. В этом смысле высказывания Маккейна следует воспринимать как сигнал, а события в Гонконге - рассматривать как один из этапов реализации этого плана.

Основные принципы противодействия цветным революциям таковы:

1. Бороться с цветными революциями, являющимися технологиями государственных переворотов, можно только с помощью технологий такого же уровня. Отдельные меры, средства и методы здесь не принесут пользы.

2. Необходимо своевременно выявлять и перекрывать каналы заведения денег для организации цветных революций - цветная революция не начнется, пока в стране не будут скрыто заведены и размещены в национальных банках и фондах значительные денежные средства. Операция по их заведению в страну может начаться яза полтора-два года до реального начала революционных событий.

3. Необходимо сделать так, чтобы основная ударная сила цветных революций - пассионарная и супер подвижная молодежь в возрасте от 16 до 35 лет потеряла свою подвижность и подверженность влиянию идеологии цветных революций. Добиться этого можно только вовлекая молодежь во всевозможные молодежные общественные организации и движения, в массовый спорт, и т.д. При этом опыт такой работы с молодежью, накопленный «Молодой гвардией», «Наши», полезен, но он слишком односторонен и от цветной революции не спасет.
4. Цветная революция в России может начать развиваться под лозунгами регионального сепаратизма и под руководством региональных лидеров. В этом плане надо уделить внимание проблемным регионам - Кавказу, Сибири и Дальнему Востоку, где региональная политика федерального центра в 20122013 гг. потерпела ряд ощутимых неудач.

5. Ну и, наконец, в России должна быть выработана собственная модель противодействия цветным революциям, как в самой России, так и на пространстве СНГ, в ЦА и других регионах, в который Россия имеет свои национальные интересы. С цветными революциями бороться можно, поскольку их ход может быть предсказан и спрогнозирован заранее. Есть опыт Беларуси, которая справилась с «васильковой революцией» весьма изящным способом: ее спецслужбы не препятствовали протестующим, но отбирали у них палатки, продукты и все, необходимое для организации протестного лагеря. Есть еще пример цветной революции в Узбекистане, которая была подавлена силой оружия.

Существует система мер, которая помогает уменьшить риски возникновения цветных революций. Первый комплекс мер направлен на выявление и перекрытие финансовых потоков, идущих на финансирование протестного движения. Вторая группа мер направлена на вовлечение социальной базы протестного движения - молодежи в возрасте от 18 до 35 лет - в деятельность общественных организаций проправительственной направленности. Третья группа мер - создание в обществе «клапанов по выпуску пара», сброса напряженности, не позволяющих обществу «перегреваться» наподобие парового котла и затем выплескивать накопившуюся энергию в виде социального взрыва.

Президентом и Правительством России должна быть создана общегосударственная система противодействия цветным революциям, имеющая четкий план действий, которая затем будет востребована и другими постсоветскими странами.

\section{Библиография:}

1. Бартош А. Гибридные войны во внешней политике CША и НATO. // Независимое военное обозрение. 2010 , 10 окт. URL: http://nvo.ng.ru/concepts/2014-10-10/1_nato.html (дата обращения 12.05.2015)

2. Маккейнпророчит «арабскийсценарий» России,КитаюиИзраилю.//MKRU.http://www.mk.ru/politics/news/2011/08/24/617060makkeyn-prorochit-quotarabskiy-stsenariyquot-rossii-kitayu-i-izrailyu.html (дата обращения 12.05.2015)

3. Codagnone C., Filippov V. Equity, exit end national identity in a multinational federation: the "multi-cultural constitutional patriotism" project in Russia // Journal of ethnic and migration studies. 2000. V. 26. № 2.. P. 263-288.

4. О.Г. Карпович Особенности позиций российских и американских экспертов по вопросам демократизации Ближнего Востока // Политика и Общество. - 2013. - 5. - С. 563 - 567. DOI: 10.7256/1812-8696.2013.05.4. 
DOI: $10.7256 / 1811-9018.2015 .7 .15832$

При цитировании этой статьи сноска на доі обязательна

Государственная безопасность

5. Карпович О.Г. Цветные революции как инструмент системной дестабилизации политических режимов: угрозы и вызовы для России // Национальная безопасность / nota bene. - 2015. - 1. - C. 73 - 87. DOI: 10.7256/2073-8560.2015.1.14142.

6. Курилкин А.В. Эволюционное развитие психологической борьбы: от пропаганды к психологическим операциям // Международные отношения. - 2014. - 3. - C. 472 - 474. DOI: 10.7256/2305-560X.2014.3.11855.

7. Петренко А.И. Теоретические основы организации противодействия использованию арсенала сил, средств и методов информационно-психологической войны в политических целях // Тренды и управление. - 2014. - 2. - C. 154 - 167. DOI: 10.7256/2307-9118.2014.2.12412.

8. Виноградова Е.А. Информационные войны в Латинской Америке // Тренды и управление. - 2014. - 4. - C. 372 - 384. DOI: 10.7256/2307-9118.2014.4.13080.

\section{References (transliterated):}

1. Bartosh A. Gibridnye voiny vo vneshnei politike SShA i NATO. // Nezavisimoe voennoe obozrenie. 2010,10 okt. URL: http://nvo. ng.ru/concepts/2014-10-10/1_nato.html (data obrashcheniya 12.05.2015)

2. Codagnone S., Filippov V. Equity, exit end national identity in a multinational federation: the "multi-cultural constitutional patriotism” project in Russia // Journal of ethnic and migration studies. 2000. V. 26. № 2.. P. 263-288.

3. O.G. Karpovich Osobennosti pozitsii rossiiskikh i amerikanskikh ekspertov po voprosam demokratizatsii Blizhnego Vostoka // Politika i Obshchestvo. - 2013. - 5. - C. 563 - 567. DOI: 10.7256/1812-8696.2013.05.4.

4. Karpovich O.G. Tsvetnye revolyutsii kak instrument sistemnoi destabilizatsii politicheskikh rezhimov: ugrozy i vyzovy dlya Rossii // Natsional'naya bezopasnost' / nota bene. - 2015. - 1. - C. 73 - 87. DOI: 10.7256/2073-8560.2015.1.14142.

5. Kurilkin A.V. Evolyutsionnoe razvitie psikhologicheskoi bor'by: ot propagandy k psikhologicheskim operatsiyam // Mezhdunarodnye otnosheniya. - 2014. - 3. - C. 472 - 474. DOI: 10.7256/2305-560X.2014.3.11855.

6. Petrenko A.I. Teoreticheskie osnovy organizatsii protivodeistviya ispol'zovaniyu arsenala sil, sredstv i metodov informatsionnopsikhologicheskoi voiny v politicheskikh tselyakh // Trendy i upravlenie. - 2014. - 2. - C. 154 - 167. DOI: 10.7256/23079118.2014.2.12412.

7. Vinogradova E.A. Informatsionnye voiny v Latinskoi Amerike // Trendy i upravlenie. - 2014. - 4. - C. 372 - 384 . DOI: $10.7256 / 2307-9118.2014 .4 .13080$ 